\title{
Internal quality assurance in a clinical virology laboratory. II. Internal quality control
}

\author{
J J Gray, T G Wreghitt, T A McKee, P McIntyre, C E Roth, D J Smith, G Sutehall, \\ G Higgins, R Geraghty, R Whetstone, U Desselberger
}

\begin{abstract}
Aims-In April 1991 additional quality control procedures were introduced into the virology section of the Clinical Microbiology and Public Health Laboratory, Cambridge. Internal quality control (IQC) samples were gradually included in the serological assays performed in the laboratory and supplemented kit controls and standard sera.

Methods-From April 1991 to December 1993, 2421 IQC procedures were carried out with reference sera.

Results-The IQC samples were evaluated according to the Westgard rules. Violations were recorded in 60 of $1808(3.3 \%)$ controls and were highest in the IQC samples of complement fixation tests $(25 / 312(8 \%)$ of controls submitted for complement fixation tests).

Conclusions-The inclusion of IQC samples in the serological assays performed in the laboratory has highlighted batch to batch variation in commercial assays. The setting of acceptable limits for the IQC samples has increased confidence in the validity of assay results.

(f Clin Pathol 1995;48:198-202)
\end{abstract}

Keywords: Internal quality control, quality assurance, virology.

Quality control measures permit the assessment of accuracy and precision in assays performed in the diagnostic laboratory. Their inclusion is designed to increase the probability that assay results reported by the laboratory are valid and that clinicians may confidently use those results when making diagnostic or therapeutic decisions.

For many years internal quality control (IQC) procedures have played an essential part in monitoring the day to day performance of assays used in clinical biochemistry departments. To date, most diagnostic microbiology laboratories (including microbial serology) have relied on control material supplied as an integral part of commercial assays. Although kit controls can be used to determine whether a particular assay run is acceptable they are not capable of monitoring batch to batch variation.

Internal quality control operates by detecting errors which may be random or systematic. Random errors are difficult to eliminate but may be minimised through training and supervision. System based errors may be related to the sensitivity, specificity, reproducibility, or stability of an assay. Although the results of serological assays may be expressed in terms of positivity or negativity, most are expressed as antibody titres or ratios (for example, in enzyme linked immunosorbent assays (ELISAs) as the ratio of the optical density (OD) of the test sample to the OD of the cut off control) or unit values or concentrations (for example, when international, national or arbitrary standards are included). Therefore, most results are expressed as numerical values making them amenable to simple statistical analysis.

Internal quality control samples are included in the assays performed in the laboratory and, when the results lie within pre-determined limits, are used to validate the test results. ${ }^{1}$ IQC samples are also useful to monitor the performance of equipment and the stability of reagents indirectly. IQC samples can be international, national or local standard sera or pools of serum samples, well characterised in previous assays, exhibiting values within clinically significant ranges. A sufficient volume of each control is required so that IQC samples can be included in each test run enabling intraand inter-batch assay variation to be monitored continuously.

From April 1991 to December 1993, 2421 IQC samples (assay controls), in addition to and independent of kit controls and standard sera, were gradually included in 17 serological assays performed at the Clinical Microbiology and Public Health Laboratory, Cambridge.

\section{Methods}

Local sera, well characterised "in house" in previous assays, or international or national serum standards with values within clinically significant ranges were included in a number of assays performed in the laboratory (table 1). The results obtained with patients' serum samples in these assays were only considered valid if the control values lay within their expected ranges.

The mean or target value and the standard deviation (SD) of the proposed assay control were calculated from the results obtained after testing the sample on 20 separate occasions. The SD is a measure of the scatter of values around a mean and is used to set acceptable limits for results subsequently obtained with the assay control. Control serum samples exhibit a normal stochastic distribution of results, therefore $95.5 \%$ of the values should lie within 

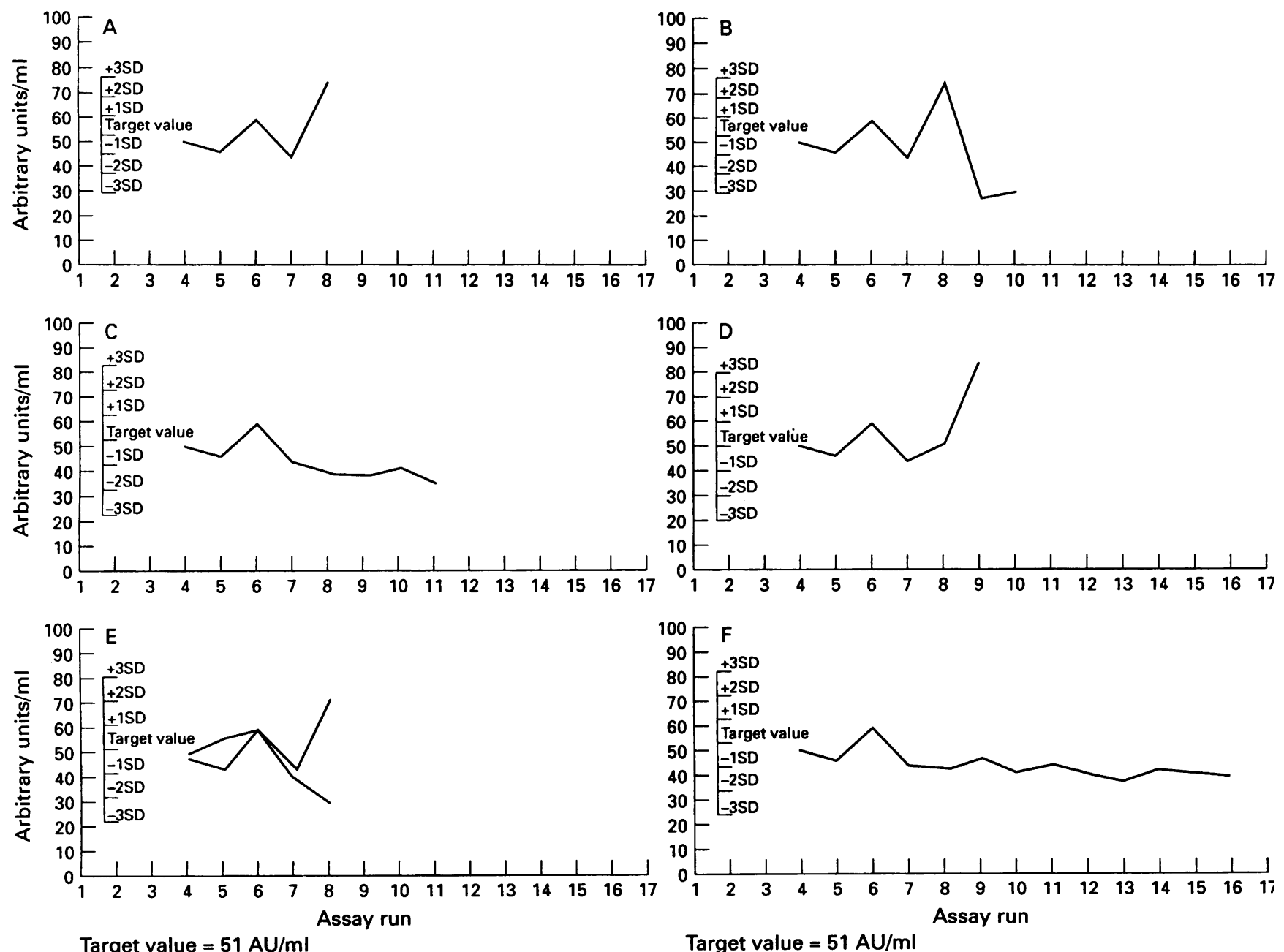

Figure 1 Violations of the Westgard rules. A-C: Warning rules (A: $\left.1_{2 S D} ; B: 2_{2 S D} ; C: 4_{1 S D}\right)$. D-F: Mandatory rules (D: $\left.1_{3 S D} ; E: R_{4 S D} ; \mathrm{F}: 10_{x}\right)$.

\pm 2 SD of the mean or target value and $99 \cdot 7 \%$ within $\pm 3 S D{ }^{2}$

Shewhart plots ${ }^{3}$ were drawn, with the target

Table 1 IQC material used for assay controls

\begin{tabular}{|c|c|}
\hline Assay & Control sera \\
\hline HIV $1+2$ & HIV 1 low positive (DMR)* \\
\hline y ELISA & HIV 2 low positive (DMR) \\
\hline HAV total antibody ELISA & Pool of positive sera \\
\hline HAV IgM ELISA & Pool of positive sera \\
\hline HBsAg ELISA & Serum containing $1 \mathrm{IU} / \mathrm{ml}$ \\
\hline HBsAg ELISA & Serum containing $100 \mathrm{IU} / \mathrm{ml}$ \\
\hline HBsAg ELISA & Serum containing $1000 \mathrm{IU} / \mathrm{ml}$ \\
\hline HBs ELISA & Serum containing $10 \mathrm{mlU} / \mathrm{ml}$ \\
\hline anti-HBs ELISA & Serum containing $120 \mathrm{mlU} / \mathrm{ml}$ \\
\hline $\begin{array}{l}\text { anti-HBs ELISA } \\
\text { anti-HBc ELISA }\end{array}$ & $\begin{array}{l}\text { Serum containingg } 600 \mathrm{mlU} / \mathrm{ml} \\
\text { Pool of positive sera }\end{array}$ \\
\hline HCV antibody ELISA & Positive control serum (DMR) \\
\hline Rubella SRH & $15 \mathrm{IU} / \mathrm{ml}$ serum (DMR) \\
\hline Rubella latex aggl & $250 \mathrm{IU} / \mathrm{ml}$ serum \\
\hline$T$ gondii late & $\begin{array}{l}\text { Antibody pos } \\
\text { (blood don }\end{array}$ \\
\hline ody & Pool of positive sera \\
\hline $\begin{array}{l}L \text { pneumophil } \\
\text { HSV IgG EI }\end{array}$ & $\begin{array}{l}\text { Pool of positive sera } \\
\text { Antibody positive serum (blood }\end{array}$ \\
\hline CMV IgG ELIS & Antibody positive serum (blood \\
\hline VZV IgG & $\begin{array}{l}\text { Antibody positive serum (blood } \\
\text { donation) }\end{array}$ \\
\hline Respiratory CFT & donat \\
\hline Respiratory CFT & Blood donatio \\
\hline
\end{tabular}

* DMR: Division of Microbiological Reagents, Central Public Health Laboratory, London.

** Regional Blood Transfusion Centre, Cambridge.

All sera not designated DMR or blood donation were local "in-house" sera.

CMV = cytomegalovirus; $\quad C F T=$ complement fixation test $\mathrm{HAV}=$ hepatitis A virus. value, and the limit values of $\pm 1 S D, \pm 2 S D$ and $\pm 3 S D$ delineated for each control used. Subsequent values obtained with the assay controls were plotted and Westgard rules were applied to determine the validity of each assay run. Westgard rules define specific performance limits and are designed to detect both random and systematic errors. ${ }^{3}$ Three of the six commonly used Westgard rules are warning rules whose violation should trigger a review of test procedures, reagent performance and equipment calibration, and three are mandatory rules which, if broken, should result in the rejection of the results obtained with patients' serum samples in that assay. Figures $1 \mathrm{~A}$ to $1 \mathrm{C}$ illustrate the three warning rules and figs $1 D$ to $1 \mathrm{~F}$ the three mandatory rules.

Warning rule $1_{2 S D}$ (fig $1 \mathrm{~A}$ ) is violated if the control value exceeds the mean by $\pm 2 S D$ (an event likely to occur normally in less than 5\% of cases). Warning rule $2_{2 \mathrm{SD}}$ (fig $1 \mathrm{~B}$ ) detects systematic errors and is violated when two consecutive control values exceed the target value on the same side of the mean by $\pm 2 S D$. Warning rule $4_{1 S D}$ (fig $1 \mathrm{C}$ ) is violated if four consecutive control values exceed the same limit (mean + 1SD or mean - 1SD) and may indicate the need to perform instrument maintenance or reagent calibration.

Mandatory rule $1_{3 S D}$ (fig $1 D$ ) applies when 

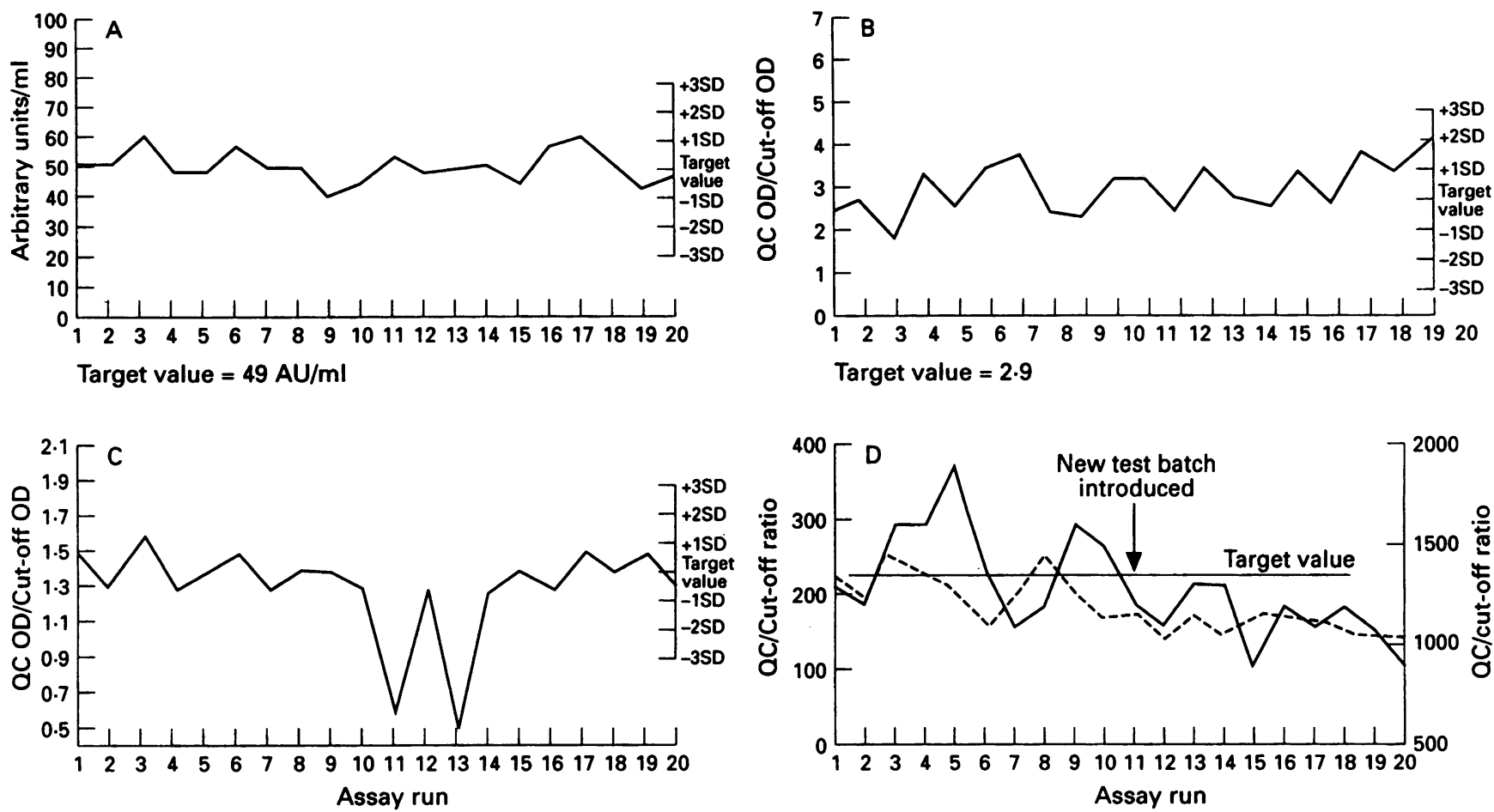

$100-1000 \mathrm{ng} / \mathrm{ml}$ control

Figure 2 Shewhart plot of A: VZV IgG ELISA IQC (violations of the Westgard rules not detected); B: HIV antibody ELISA IQC (violations of the Westgard rules not detected); C: HCV antibody ELISA IQC (violations of the $1_{3 S D}$ rule detected); D: HBsAg ELISA IQC (violation of the 10 ${ }_{x}$ rule detected).

the control value exceeds the target value by $\pm 3 \mathrm{SD}$; the assay run is then regarded as out of control. Mandatory rule $R_{4 S D}$ (fig $1 E$ ) is a range rule within a run and is only applied when the control is tested in duplicate. The rule is violated when the difference in SD between the duplicates exceeds 4 SD. The $10_{x}$ (mandatory) rule (fig $1 \mathrm{~F}$ ) detects systematic error and is violated when the last 10 consecutive control values are on the same side of the mean or target value.

In the IQC scheme reported here the $R_{4 S D}$ range rule was not applied as the assay controls were tested singly.

\section{Results}

Examples of Shewhart plots illustrating the performance of the assay controls, used in the varicella zoster virus (VZV) IgG antibody ELISA, HIV $1+2$ antibody ELISA, hepatitis $C$ virus (HCV) antibody ELISA, and hepatitis $B$ virus surface antigen (HBsAg) ELISA over 20 consecutive assay runs, are shown in figs $2 \mathrm{~A}$ to $2 \mathrm{D}$, respectively.

No violations of the Westgard rules were found with the assay controls in the VZV IgG ELISA or the HIV $1+2$ antibody ELISA during the period illustrated in figs $2 \mathrm{~A}$ and $2 \mathrm{~B}$. In the HCV antibody ELISA the $1_{3 S D}$ rule was violated on two occasions triggering the rejection of those particular assay runs (fig $2 \mathrm{C}$ ). A reduction in the sensitivity of the $\mathrm{HBsAg}$ ELISA after the introduction of a new batch of reagents was indicated by violation of the $10_{\mathrm{x}}$ rule (fig $2 \mathrm{D}$ ).
A total of 2421 assay controls were included in the serological assays performed between 1991 and 1993. The Westgard rules were applied to the results obtained with 1808 assay controls included in 891 assays. A total of 29 $(1.6 \%)$ violations of the $1_{3 \mathrm{SD}}$ rule and 31 $(1 \cdot 71 \%)$ violations of the $10_{x}$ rule were detected (table 2). On 18 occasions, both the $1_{3 \mathrm{SD}}$ and the $10_{x}$ rules were violated at the same time. Table 3 illustrates the results obtained with the HIV 1 IQC sample in a HIV $1+2$ (combined) antibody ELISA when a new batch of assay reagents was introduced. The increased sensitivity of the new batch changed the expected mean or target value of the IQC sample from $2 \cdot 8$ (OD of the sample:OD of the cut off value) to $4 \cdot 4$. Therefore, if the target value and the performance limits had not been recalculated, the results of two assay runs, performed with

Table 2 Assay controls and violations of the Westgard rules, $1_{3 S D}$ and 10

\begin{tabular}{llll}
\hline & & \multicolumn{2}{c}{ Rule Violation } \\
\cline { 3 - 4 } Assay control & $\begin{array}{l}\text { Number } \\
\text { tested }\end{array}$ & $1_{3 S D}$ & $10_{x}$ \\
\hline HBsAg $(1 \mathrm{IU} / \mathrm{ml})$ & 278 & 8 & 7 \\
$\quad(100 \mathrm{IU} / \mathrm{ml})$ & 318 & 3 & 7 \\
$\quad(1000 \mathrm{IU} / \mathrm{ml})$ & 317 & 1 & 5 \\
Anti-HBs $(10 \mathrm{mlU} / \mathrm{ml})$ & 22 & 1 & 0 \\
$\quad(120 \mathrm{mlU} / \mathrm{ml})$ & 22 & 0 & 0 \\
$\quad(500 \mathrm{mlU} / \mathrm{ml})$ & 22 & 0 & 0 \\
Anti-HBc & 25 & 0 & 0 \\
Anti-HCV & 94 & 3 & 1 \\
Anti-HIV 1 $1+2 \mathrm{a}$ & 278 & 4 & 4 \\
Anti-HIV 1+2 b & 278 & 6 & 6 \\
VZV IgG & 108 & 2 & 1 \\
CMV IgG & 23 & 0 & 0 \\
HSV IgG & 23 & 1 & 0 \\
Total & 1808 & 29 & 31 \\
& & $(1 \cdot 60 \%)$ & $(1 \cdot 71 \%)$ \\
\hline
\end{tabular}


Table 3 Violation of the Westgard rule $1_{3 S D}$, caused by introducing a new batch of assay reagents: HIV 1 control in the HIV $1+2$ antibody ELISA

\begin{tabular}{|c|c|c|c|c|c|c|c|}
\hline \multirow[b]{2}{*}{$\begin{array}{l}\text { Assay run } \\
\text { number }\end{array}$} & \multirow[b]{2}{*}{$\begin{array}{l}\text { Ratio of } O D \\
\text { sample to } O D \\
\text { cut off }\end{array}$} & \multirow[b]{2}{*}{ Assay batch } & \multicolumn{3}{|c|}{ Control parameter } & \multicolumn{2}{|l|}{ Acceptability } \\
\hline & & & Mean & $S D$ & $\begin{array}{l}\text { Acceptable } \\
\text { range }\end{array}$ & $\begin{array}{l}\text { If control } \\
\text { parameters } \\
\text { recalculated }\end{array}$ & $\begin{array}{l}\text { If control } \\
\text { parameters NOT } \\
\text { recalculated }\end{array}$ \\
\hline & & & \multirow{21}{*}{$4 \cdot 4^{* *}$} & 0.95 & $0.05-5 \cdot 6$ & & \\
\hline 1 & $2 \cdot 6$ & A & & & & Yes & Yes \\
\hline 2 & 1.6 & A & & & & Yes & Yes \\
\hline 3 & $4 \cdot 2$ & A & & & & Yes & Yes \\
\hline 4 & 1.8 & A & & & & Yes & Yes \\
\hline 5 & $2 \cdot 7$ & $\ddot{A}$ & & \multirow{16}{*}{0.83} & \multirow{16}{*}{$1.9-6.9$} & Yes & Yes \\
\hline 6 & $5 \cdot 2$ & B & & & & Yes & Yes \\
\hline 7 & 3.5 & B & & & & Yes & Yes \\
\hline 8 & $5 \cdot 0$ & B & & & & Yes & Yes \\
\hline 9 & $3 \cdot 3$ & B & & & & Yes & Yes \\
\hline 10 & $4 \cdot 6$ & B & & & & Yes & Yes \\
\hline 11 & $3 \cdot 5$ & B & & & & Yes & Yes \\
\hline 12 & $3 \cdot 7$ & B & & & & Yes & Yes \\
\hline 13 & $4 \cdot 0$ & B & & & & Yes & Yes \\
\hline 14 & $4 \cdot 2$ & B & & & & Yes & Yes \\
\hline 15 & $4 \cdot 6$ & B & & & & Yes & Yes \\
\hline 16 & 5.7 & B & & & & Yes & No*** \\
\hline $\begin{array}{l}10 \\
17\end{array}$ & 3.7 & B & & & & Yes & Yes \\
\hline 18 & $4 \cdot 7$ & B & & & & Yes & Yes \\
\hline 19 & 6.0 & B & & & & Yes & $\mathrm{No}^{* * *}$ \\
\hline 20 & 3.9 & B & & & & Yes & Yes \\
\hline 21 & $3 \cdot 3$ & A & \multirow{7}{*}{$2 \cdot 8$} & \multirow[t]{7}{*}{0.95} & \multirow[t]{7}{*}{$0 \cdot 05-5 \cdot 6$} & Yes & Yes \\
\hline 22 & $4 \cdot 1$ & A & & & & Yes & Yes \\
\hline 23 & $3 \cdot 7$ & A & & & & Yes & Yes \\
\hline 24 & $4 \cdot 1$ & A & & & & Yes & Yes \\
\hline 25 & $3 \cdot 6$ & A & & & & Yes & Yes \\
\hline 26 & $3 \cdot 2$ & A & & & & Yes & Yes \\
\hline 27 & 1.7 & A & & & & Yes & Yes \\
\hline
\end{tabular}

* Calculated from the results from 20 assay runs with batch $A$. ** Control parameters recalculated using results obtained with batch B.

$* * *>3 S D$ above the mean.

the new batch of reagents, would have been rejected through violations of the $1_{3 \mathrm{SD}}$ rule.

In the remaining 613 assays the Westgard rules were not applicable as the results were expressed either as an antibody titre or as positive or negative. In the Legionella pneumophila RMAT (57 assays), Toxoplasma gondii latex agglutination test (174 assays), hepatitis A virus total antibody ELISA (70 assays), hepatitis A virus IgM antibody ELISA (37 assays), and the Paul-Bunnell assay (57 assays), the results obtained with the assay controls were within the expected ranges (data not shown). In the rubella virus antibody assays, single radial haemolysis (79 assays) and the latex agglutination assay (113 assays) the controls were outside their expected ranges in one of $79(1.26 \%)$ and four of $113(3.53 \%)$ assays, respectively (data not shown). In the complement fixation tests two sera were included in 26 assay runs and were tested with influenza $A$, influenza $B$, adenovirus, Chlamydia sp, Coxiella burnetii, and Mycoplasma pneumoniae antigens. The results obtained with these controls show that 25 of $312(8.0 \%)$ procedures were outside their expected ranges (table 4 ).

\section{Discussion}

The inclusion of IQCs with the ability to detect random and systematic errors permits the day to day monitoring of assay performance independently of kit controls and increases the probability that results obtained with clinical samples are valid.

The combination of Westgard rules used ${ }^{14}$ and their warning or mandatory functions should be governed by the need to reject true errors but not to reject valid test results. If all test results were rejected when the assay control

Table 4 Results obtained with assay controls in the complement fixation tests

\begin{tabular}{|c|c|c|c|c|c|c|}
\hline Control & Antigen & Titre & Acceptable range & Number tested & $\begin{array}{l}\text { Number outside } \\
\text { acceptable range }\end{array}$ & Per cent \\
\hline A & $\begin{array}{l}\text { Influenza A } \\
\text { Influenza B } \\
\text { Chlamydia } \\
C \text { Burnetti } \\
\text { Adenovirus } \\
\text { M pneumoniae }\end{array}$ & $\begin{array}{r}8 \\
<8 \\
16 \\
<8 \\
32 \\
<8\end{array}$ & $\begin{array}{l}<8-16 \\
<8-8 \\
8-32 \\
<8-8 \\
16-64 \\
<8-8\end{array}$ & $\begin{array}{l}26 \\
26 \\
26 \\
26 \\
26 \\
26\end{array}$ & $\begin{array}{l}0 \\
1 \\
5 \\
0 \\
5 \\
1\end{array}$ & $\begin{array}{r}0 \cdot 0 \\
3 \cdot 8 \\
19 \cdot 2 \\
0 \cdot 0 \\
19 \cdot 2 \\
3 \cdot 8\end{array}$ \\
\hline Subtotal & & & & 156 & 12 & $7 \cdot 7$ \\
\hline B & $\begin{array}{l}\text { Influenza A } \\
\text { Influenza B } \\
\text { Chlamydia } \\
C \text { burnetti } \\
\text { Adenovirus } \\
M \text { pneumoniae }\end{array}$ & $\begin{array}{r}16 \\
8 \\
<8 \\
<8 \\
<8 \\
8\end{array}$ & $\begin{array}{l}8-32 \\
<8-16 \\
<8-8 \\
<8-8 \\
<8-8 \\
<8-16\end{array}$ & $\begin{array}{l}26 \\
26 \\
26 \\
26 \\
26 \\
26\end{array}$ & $\begin{array}{l}8 \\
0 \\
3 \\
0 \\
1 \\
1\end{array}$ & $\begin{array}{r}30 \cdot 8 \\
0 \cdot 0 \\
11 \cdot 5 \\
0 \cdot 0 \\
3 \cdot 8 \\
3 \cdot 8\end{array}$ \\
\hline Subtotal & & & & 156 & 13 & $8 \cdot 3$ \\
\hline Total & & & & 312 & 25 & $8 \cdot 0$ \\
\hline
\end{tabular}


value was greater than the mean $\pm 2 S D$, then failure to allow for appropriate control values (for example, changing between batches of reagents) would result in a proportion of assay runs being falsely rejected.

Data obtained with the assay controls can also be used to set acceptable limits in assays in which anonymous samples are tested as part of an internal quality assessment scheme (IQAS) (see Part I). This can be accomplished by calculating the coefficient of variation $(\mathrm{CV})$ from the mean and SD of the assay control. The CV can then be used to determine the range of acceptable values when a sample is repeated. This is particularly useful in assays where numerical or unit values are obtained. A discrepancy would be recorded if the difference between the two values was greater than the CV.

The CV should be calcuated from an assay control with a concentration of antigen or antibody that is close to that of the test sample, as the $\mathrm{CV}$ will change at different concentrations. In the anti-HBs assay the intermediate control had a CV of $15 \cdot 2 \%$ and a discrepancy would be recorded if there was a greater than $15 \cdot 2 \%$ difference between the results of the named and anonymous sample, whereas the high control had a CV of $13 \cdot 5 \%$.

Internal quality control operates by detecting errors. Random errors are impossible to eliminate but may be minimised through training and adherence to standard operating procedures. System based errors may be related to the sensitivity or specificity of an assay, the use of non-standard methods, poor equipment calibration, or the instability of reagents.
Although errors will inevitably occur, they can be significantly reduced through the introduction of IQC as an integral part of a comprehensive IQAS. Training must be continually updated with regular meetings to discuss quality control failures and successes, changes in standard operating procedures, the introduction of new assays, and the operation of new equipment. Publication of results within the laboratory and encouragement of staff to discuss technical problems and possible solutions can significantly improve the overall performance. Problems and inconsistencies in laboratory procedures can be identified through the IQAS and the use of IQC will increase the confidence in test results.

In conclusion, IQC procedures were performed as part of a comprehensive IQAS where some specimens received in the laboratory were resubmitted for testing anonymously. The conduct of and the results achieved with the IQAS are presented in Part I.

We thank all staff of the Virology section of Clinical Microbiology and Public Health Laboratory for their support of the IQA Scheme and IQC measures and for fruitful discussion. Thanks are also due to $M$ Farrington, H Ludlam, M Wilcox, D Brown, MAT Coles, and M Amphlett for critical reading of the manuscript.

1 Westgard JO, Koch DD, Oryall J, Quam EF, Feldbruegge $\mathrm{DH}$, Dowd DE, et al. Selection of medically useful quality $\mathrm{DH}$, Dowd DE, et al. Selection of medically useful quality control procedures for individual tests done in
analytical system. Clin Chem 1990;36:230-8.

2 Taylor RN, Juong AY, Fulford KM, Przybyszewski VA, Hearn TL. Quality control for immunologic tests. Health Education and Welfare Publication No. (CDC) 79-8376. Atlanta: Centre for Disease Control, 1979:54-85.

3 Westgard JO, Hunt MR, Groth T. A multi-rule Shewhar chart for quality control in clinical chemistry. Clin Chem 1981;27:493-501.

4 Gray JJ. Internal quality assurance in a diagnostic virology laboratory. $A C M$ News 1994;10-15. 